\title{
Second Generation South Asian Businesspersons in the UK: Start- Ups, Social Connectedness, Family Influence and Co-Ethnic Professionals
}

\author{
Muhammad Tahir Rafique, \\ University of Nottingham, United Kingdom
}

\begin{abstract}
:
The context for this research study is second generation South Asian businesspersons in the UK. South Asian businesspersons are over-represented in self-employment as compared to their white majority counterpart. The aim of this research is to examine the growth of South Asian businesses in the UK. Three core themes that emerge from the literature provide a framework for the research, namely, the impact of 'push' and 'pull' factors to the self-employment in the second generation South Asians; and reliance on co-ethnic accountants. The research approach was qualitative, and conducted over a period of six months. The research makes a contribution to the Network theory of immigrant ethnic minorities. On a practical level, exploring the second generation South Asians in Britain will enhance the understanding of marketers and professional service providers who might see South Asian businesses as an emerging and growing market. The paper ends with an agenda for future research.
\end{abstract}

Paper type: Research paper

Keywords: Ethnic Minority Businesspersons, Social Connectedness, Second Generation Businesspersons, Co-ethnic Professionals 


\section{Introduction}

People of Indian and Pakistani/ Bangladeshi origin are over-represented in selfemployment compared with the white majority, based on the self-employment rates as a percentage of all in work. Sixteen per cent of the combined Pakistani/Bangladeshi group, and just over 14 per cent of the Indians are self-employed compared to 12 per cent of whites according to Labour Market Trends 1999 (Barrett et al. 2001). Ethnic minority-owned business is now an established and growing feature of contemporary Britain (Ram, 1997). The ethnic minority groups that tend to be the focus of research in Britain are largely made up of post war labour migrants and their families and descendants from the Caribbean and Indian subcontinent (Karlsen and Nazroo, 2002). A study by Ram and Carter (2001) confirmed the marked tendency for ethnic minority firms to use the services of a co-ethnic accountant. Accountants and their clients share similar characteristics: small, independent practices typically serve small, local companies, and ethnic minority practices typically serve ethnic minority clients (Marlow and Carter, 2003). Ram (1997) acknowledges the differences between ethnic minority groups; between different generations; between different sectors; and between different stages of development. This complexity of the lives of second generation Indians and Muslims is further highlighted by Mand (2006), Dhaliwal (2004), and Ramadan (1998). McPherson (2007) claim that the complexity of the lives of second generation Indians is of both academic and managerial interest, and in Britain, it has become an area of cultural discourse too; whereas, Ramadan (1998) notices that there is a rift between generations, because, unlike the first-generation immigrants, these people (second generation Muslims) are attempting to create roles for themselves at the intellectual and social level.

\section{Literature Review}

South Asian (SA) families play an important role in the establishment and well-being of the family business according to Ram (1997). Ethnicity is important in gaining access into co-ethnic firms, and is helpful to the generation of trust between client and accountant. Oc et al. (1997) note in their study of business support for ethnic minority groups, 'the networking of ethnic minority businesses may encourage solidarity but may also result in further isolation and marginalisation', whereas, Ram (1994) classes this as 'double-edged' nature of co-ethnic networks. Whilst noting the experiences of second generation South Asians in Britain, McPherson (2007) refer them as 'caught between breakout and adjustment' and that even though a second generation may be more western in the work environment and in social situations, they also have pressures from the first generation to conform to home country standards. Dhaliwal (2004) claims that despite the 'pull' assertions, second generation Asians are still entering businesses with long hours, low value-added, low growth potential and highly dependant on family finance.

The following areas need further explanations: (i) SA and self-employment, (ii) SA businesspersons and social connectedness, and (iii) reliance on co-ethnic accountants.

International Journal of Management and Applied Research, 2014, Vol. 1, No. 2 


\section{Research Methodology}

This paper is based on a qualitative study of 14 interviews conducted between August and November 2006. Purposive sampling was used for in-depth investigation of a small number of cases. In reference to Bowen (2005: 217), "the emphasis [of qualitative research] is on quality rather than quantity, the objective is not to maximise numbers but to become 'saturated' with information on the topic". For the purpose of this paper, 'South Asians' are described as 'those who regard themselves as having family origins in the Indian sub-continent, primarily India, Pakistan and Bangladesh (Gidoomal, 1997). Second generation South Asians are the first generation children born in the UK, but their parents were post world war two migrants. In this paper, SA refers to second generation South Asian businesspersons. The businesspersons were identified through contacts or referrals, all based in the North West of England. They are responsible for the day to day management of the business and either wholly or partly owns the business. The sample is representative of many other second generation businesses across the country. To generate rich data from a range of contexts, with a view to revealing a variety of aspects of South Asian businesses, the sample was selected from two distinctly different locations; Manchester; a cosmopolitan city, and East Lancashire area, which is made up of old mill towns, and is one of the deprived regions in the country.

According to Cepeda and Martin (2005: 872), "it is essential to ensure that findings are based on researcher's interaction with the social actors, their immersion in the research situation, and hence their interpretation of the participant's subjective understanding". The quantitative data might not capture the depth, breadth and intensity of the social and cultural issues. A single case study approach will be insufficient to cover the ethnicity and diversity of South Asian business community and the accountants which comprise of Pakistan, India and Bangladesh for this research. Cepeda and Martin (2005) suggest an interplay between the conceptual framework and the research cycle enables building knowledge and theory.

Qualitative research is best used for problems requiring insight and understanding. It deals with explanatory concepts (Robson and Foster, 1989). Blaxter et al (2001: 65) explain qualitative research "tends to focus on exploring, in as much detail as possible, smaller numbers of instances or examples which are seen as being interesting or illuminating, and aims to achieve 'depth' rather than 'breadth"'. Interpretive researchers start out with the assumption that access to reality is only through social constructions such as language, consciousness and shared meanings (Myers, 1997). Concerned with social interactions, interpretive research assumes that all human actions are meaningful. The interpretive production of meaning, however, warrants scrutiny as it rests heavily on the authenticity of individual's subjective experience (Garrick, 1999). According to Denscombe (2002), interpretivism has emerged from a radical, minority position to an established alternative orthodoxy.

International Journal of Management and Applied Research, 2014, Vol. 1, No. 2 


\section{Research Findings}

The issues relating to social connectedness; business and social networks; and, family influence and power are further explored. This strategy endeavours to initiate further reflection and reflexivity by uncovering and confronting these issues.

\section{1 Becoming A Businessperson}

The question, how the participants got involved in the business was designed to understand the impact of 'push' and 'pull' factors on South Asian self-employment, as described by Ram (1997), and Baus and Goswami (1999). In the non-family owned businesses, the decision to become a businessperson was to seize the opportunity, personal ambition or the desire to become one's own boss; whereas, in the family owned businesses, the reasons to join or stay within the family business were cultural; sense of responsibility; and availability of the participant after finishing their education.

'I spotted the opportunity, more than anything else. I had been involved in other businesses (as an employee)' (Pakistani Male, Courier Services - East Lancashire).

'....my father started the business, as I am the eldest, it is my responsibility to get involved' (Pakistani Male, Grocery Store - Manchester). The participant left his job as 'Head of the Department' in a multinational company to run a grocery store when his father decided to retire.

'.... I wanted to be close to my family, I resigned from my job in London and started my own business, here' (Indian Female, Beauty Therapist - East Lancashire).

In contrast to the findings of Dhaliwal (2004), SA businesspersons are not entering businesses with long hours, low value-added or low growth potential. Since, some SA businesspersons are starting traditionally non-Asian businesses, such as courier service or beauty therapy, they do not seem to rely on ethnic minority networks, but get involved in mainstream business networks, including the membership of local chambers of commerce. The reasons to start own business or to join family business were personal based on the family values, entrepreneurial acumen and sense of responsibility.

\section{2 The Role of Family Members}

The roles, responsibilities and influence of family members varied from business to business, where the first generation did not have any first hand experience of running the business, the family members only provided the admin support and promoted the business through personal contacts and had no involvement in making decisions. But in the family businesses, even though the first generation businesspersons were officially retired or semi retired and day to day management was the responsibility of the SA businesspersons, the first generation still had a big say; in some cases the final say. There appeared to be some power struggle as well.

International Journal of Management and Applied Research, 2014, Vol. 1, No. 2 
'I changed the accountant, while my dad was on holidays ...yeah, dad was away and I did not get on with him (the Asian accountant hired by his father)' (Male Indian Bakery Business, East Lancashire).

This illustrates the shift in the attitudes of SA business persons. The networks developed by the first generation migrants are not sometimes valued or strengthened by the SA businesspersons. The impact of power struggle within family owned businesses and strategically timed decision making adds to the complexity of the Network theory of immigrant ethnic minorities.

\section{3 Social Connectedness}

The participants acknowledged the importance and the impact of strong social connectedness on first generation Asians. Although the strong social connectedness was considered beneficial, it was thought to be out of necessity rather than a choice. Within the second generation, education in the UK had helped them overcome the language barriers; and access to support networks and finance providers was not a problem any more, but it was for the first generation.

'first generation had hardly learnt to hold a proper dialogue with bank manager, if they go to the solicitors, they will fob them off....like my dad wanted to invest in a business and the solicitor made him go in circles' (Male Pakistani - Garage Business, Manchester).

Whereas in the second generation, issues of competition within community and spending more time with family members take precedent to the social connectedness.

'I think there is more jealously within the community now' (Male Indian, Manufacturing Business - East Lancashire).

'Life has got busier I think, everybody wants to do their own things' (Male Pakistani Nursing Homes Business - Manchester).

Some SA businesspersons talked about the experience of being neglected by their parents, because the parents were working long hours to start and establish their own businesses. Spending time with the immediate and extended family members was the priority of these businesspersons as opposed to work-related socialisation. This coupled with the perceived jealousy within the community seems to be adversely affecting the networking of SA businesspersons. 


\subsection{Co-ethnic Accountants}

In the family businesses, the accountants were appointed by the first generation. All the accountants appointed by the first generation were of same ethnic origin. Strong social connectedness in the first generation was the main determining factor in the appointment of the accountants.

'I think this happens with every community, not just with the Asian community. Jewish people would rather go to a Jewish accountant, English people go to English accountants, what is wrong with Asian people going to an Asian accountant? I think you feel more comfortable' (Family business where accountant was appointed by the father many years ago).

Contrary to the findings of Ram and Carter (2001) who noted a tendency for ethnic minority firms to use the services of co-ethnic accountant, the ethnicity of the accountant, according to this study was not always important. While deciding to hire the accountant, SA businesspersons seemed to be interested in the experience and reputation of the accountant. The accountant is expected to provide informal, tax efficient and personalised services on demand.

'If I want him (the accountant) at midnight, he will come along'

'I would prefer to hire Jewish accountants over all other accountants; it might come across as racist. The only reason being, they have been here longer in accountancy, if you see an accountant, his father was an accountant, his grandfather was an accountant'.

When it comes to the provision of professional services, such as accountancy, the evidence from this study does not support the premise of network theory of immigrant ethnic minorities.

\section{Conclusion}

This paper set to examine the growth of South Asian businesses in the UK. The main objective was to identify 'push' and 'pull' factors affecting the self-employment within second generation South Asians and their reliance on co-ethnic accountants.

The notion of 'Traditional Asian Business' has changed in the second generation. The only traditional businesses are the family run businesses with strong first generation influence. However, in the non-family businesses, the SA businesspersons have seized the opportunity to establish themselves in the modern business environment. The findings of this research have been as follows: (1) SA businesspersons do not rely on co-ethnic accountants and do not consider that the ethnicity is important; (2) none of the participants want their children (Third Generation) to be involved in the family business; (3) the idea of "social connectedness" is being replaced by "personal space".

International Journal of Management and Applied Research, 2014, Vol. 1, No. 2 
One of the emerging findings of this research is that the SA female businesspersons are better prepared by doing their research, exploring the support networks available before starting up their businesses. However, further research is immanent to establish the future of co-ethnic accountants as well as the very existence of the so called traditional Asian businesses in the third generation.

The shift in the work ethics and family values of the SA businesspersons, adds to the complexity of the network theory of immigrant ethnic minorities. The study was conducted in the North West of England and similar studies in the other parts of the UK might augment further dimensions of the work and family lives of SA businessperson.

\section{References}

1. Barrett, G. A.; Jones, T. P. and McEvoy, D. (2001), "Socio-economic and policy dimensions of the mixed embeddedness of ethnic minority business in Britain", Journal of Ethnic and Migration Studies, Vol. 27, No. 2, pp. 241258. https://doi.org/10.1080/13691830125088

2. Basu, A. and Goswami, A. (1999), "South Asian entrepreneurship in Great Britain: factors influencing growth", International Journal of Entrepreneurial Behaviour, Vol. 5, No. 5 pp. 251-275. https://doi.org/10.1108/13552559910300381

3. Blaxter A.; Hughes C. and Tight M. (2001), How to Research, $2^{\text {nd }}$ ed., Buckingham: Open University Press.

4. Bowen, G. A. (2005), "Preparing a qualitative research-based dissertation: Lessons learned", The Qualitative Report, Vol. 10, No. 2, pp. 208-222.

5. Cepeda, G. and Martin, D. (2005), "A review of case studies publishing in Management Decision 2003-2004: Guides and criteria for achieving quality in qualitative research", Management Decision, Vol. 43, No. 6, pp. 851-876. https://doi.org/10.1108/00251740510603600

6. Denscombe, M. (2002), Ground Rules for Good Research, Buckingham: Open University Press.

7. Dhaliwal, S. (2004), "Second/ Third Generation Asian Business Entrepreneurs in the UK", Forum Empresarial, Vol. 9, No. 2, pp. 25-45.

8. Garrick, J. (1999), "Doubting the Philosophical assumptions of interpretive research", International Journal of Qualitative Studies, Vol. 12 No.2 pp. 147 156. https://doi.org/10.1080/095183999236222

International Journal of Management and Applied Research, 2014, Vol. 1, No. 2 
9. Gidoomal, R. (1997), The UK Maharajas, London: Nicholas Brealey Publishing.

10. Karlsen, S. and Nazroo, J.Y. (2002), "Relation between racial discrimination, social class, and health among ethnic minority groups", American Journal of Public Health, Vol. 92 No. 4, pp. 624. https://doi.org/10.2105/AJPH.92.4.624

11. Mand, K. (2006), Social Capital and Transnational South Asian families: Rituals, Care and Provision, London: London South Bank University.

12. McPherson, M. (2007), "A comparison of marketing practices: perspectives from first and second generation UK South Asians", International Journal of Consumer Studies, Vol. 31, No. 2, pp. 174-186. https://doi.org/10.1111/j.1470-6431.2006.00583.x

13. Myers, M.D. (1997) "Qualitative Research in Information Systems", MIS Quarterly, Vol. 21, No. 2, pp. 241-242.

14. Oc, T.; Tiesdell, S. and Moynihan D. (1997), Urban regeneration and ethnic minority groups: training and business support in City Challenge areas, York: Joseph Rowntree Foundation.

15. Ram, M. (1994), "Unravelling social networks in ethnic minority firms", International Small Business Journal, Vol.12 No. 3, pp.42-53. https://doi.org/10.1177/0266242694123004

16. Ram, M. and Carter, S. (2001), "Smaller Practices in Profile", ACCA Research Report No. 71, London: Certified Accountants Educational Trust.

17. Ram M. and Carter, S. (2003) "Paving professional futures: Ethnic minority accountants in the United Kingdom", International Small Business Journal, Vol. 21 No. 1 pp. 55-71. https://doi.org/10.1177/0266242603021001721

18. Ramadan, T. (1998), Immigration, Integration and Cooperation Policies: Europe's Muslims find a place for themselves, available at: http://mondediplo.com/1998/04/ (Accessed on 26 October 2014).

19. Robson, S. and Foster, A. (1989), Qualitative Research in Action, London: Edward Arnold. 